\title{
Optimization of Sample Preparation Methods on Formaldehyde Analysis in Meatball with Schryver's Method
}

\author{
Febrina A. Saputri*, Nur S.B. Rosli, Wiwiek Indriyati \\ Department of Pharmaceutical Analysis and Medicinal Chemistry, Faculty of Pharmacy, \\ Universitas Padjadjaran, West Java - Indonesia
}

Submitted 10 October 2018; Revised 20 March 2019; Accepted 29 March 2019; Published 27 June 2019

*Corresponding author: febrina@unpad.ac.id

\begin{abstract}
Meatball is one of Indonesian's favorite food. However, the fraudulent traders often add carcinogen compounds, formaldehyde to ensure the meatball is not easily rotten. The purpose of this study was to find out the best sample preparation method for formaldehyde analysis in the meatball. The preparation methods were the distillation, hot immersion, and cold immersion. Formaldehyde was then analyzed by Schryver's method. UV-Vis spectrophotometer was used for quantitative analysis. The distillation method yielded the highest recovery (100.64\%) compared to hot immersion $(98.11 \%)$ and cold immersion (94.17\%). The best method was used to test the meatball samples that have been collected around Jatinangor, Indonesia. The results of the qualitative analysis for five samples of meatball showed that two samples containing formaldehyde with the highest concentration of formaldehyde in the sample B2 (14.72 ppm) and followed by B5 (8.77 ppm).
\end{abstract}

Keywords: Cold immersion, distillation, formaldehyde, hot immersion, meatball, Schryver.

\section{Optimasi Metode Preparasi Sampel untuk Analisis Formaldehid dalam Bakso dengan Metode Schryver}

\begin{abstract}
Abstrak
Bakso adalah makanan favorit orang Indonesia. Namun, pedagang yang curang seringkali menambahkan senyawa karsinogen, formaldehid untuk memperoleh bakso yang tidak mudah rusak. Tujuan dari penelitian ini adalah untuk mengetahui metode persiapan sampel terbaik untuk analisis formaldehid dalam bakso. Metode persiapannya adalah destilasi, perendaman panas, dan perendaman dingin. Formaldehid kemudian dianalisis dengan metode Schryver. Spektrofotometer UV-Vis digunakan untuk analisis kuantitatif. Metode destilasi menghasilkan perolehan kembali tertinggi(100,64\%) dibandingkan dengan perendaman panas $(98,11 \%)$ dan perendaman dingin $(94,17 \%)$. Metode terbaik ini digunakan untuk menguji sampel bakso yang telah dikumpulkan di sekitar Jatinangor, Indonesia. Hasil analisis kualitatif dari lima sampel bakso menunjukkan bahwa dua sampel mengandung formaldehid dengan konsentrasi formaldehid tertinggi dalam sampel B2 (14,72 ppm) dan diikuti oleh B5 (8,77 ppm).
\end{abstract}

Kata Kunci: Bakso, destilasi, formaldehid, perendaman dingin, perendaman panas, Schryver. 


\section{Introduction}

Several studies have shown that formaldehyde is a carcinogenic compound. ${ }^{1-6}$ Food experts have jointly agreed not to allow the addition of formaldehyde in food and beverages. This principle is known as Delaney Clause in America. ${ }^{7}$ In 2012, Indonesian Health Minister issued the regulation number 033 about Food Additives that states additional ingredients that are prohibited to be used entirely in the diet include formaldehyde. ${ }^{8}$ Although there is the regulation that prohibits the use of formaldehyde in the diet, formaldehyde still sometimes illegally used as a food preservative, such as in meatball.

The biggest problem in making meatball is to make sure the meatball does not rot quickly. Meatball must be sold out before the rotting, causing some unscrupulous sellers to resort to cheating. The addition of formaldehyde is a way to prevent decay by preserving meatball containing protein and fat. Formaldehyde acts as a preservative by coagulating proteins contained in protoplasm and nucleus that cause all the bacteria decomposing in the meatball to die. ${ }^{9}$

There are various methods of doing sample preparation to analyze formaldehyde, such as by solid phase extraction, distillation and immersion. ${ }^{10-15}$ The importance of sample preparation is to extract the formaldehyde present in the sample. The sample preparation methodalso aims to separate the bonds between the formaldehyde and the proteins sample so that the results of the sample preparation solution can detect its formaldehyde content to the maximum extent possible.

Based on this background, we optimized the sample preparation method to analyze formaldehyde of meatballs using distillation method, hot immersion and cold immersion, then the best recovery method was used to analyze the formaldehyde content of meatballs sold in Jatinangor using Schryver's method. ${ }^{16}$

\section{Methods}

2.1. Equipments

UV-Vis Spectrophotometer (Cary 50 Conc.), distillation apparatus, analytical balance, hot plate, and glassware.

\subsection{Materials}

The 37\% formaldehyde, fennilhidrazine hydrochloride, potassium ferricyanide, concentrated hydrochloric acid, and phosphoric acid were purchased from Merck, Germany. Meatball simulation was made and meatball samples were collected from Jatinangor, Indonesia.

\subsection{Maximum Wavelength Determination}

$5 \mathrm{ml}$ of $100 \mathrm{ppm}$ formaldehyde standard solution was mixed with $5 \mathrm{ml}$ of Schryver reagent, then let it reacted for 20 mins. Maximum wavelength of UV-Vis spectrophotometry was measured at $400 \mathrm{~nm}$ $800 \mathrm{~nm}$.

\subsection{Analytical Method Validation}

\subsubsection{Linearity}

Formaldehyde solution was prepared at the concentration of $8,12,16,20,24,28 \mathrm{ppm}$. $5 \mathrm{ml}$ of each concentration was then pippetted and was reacted with Schryver reagent for 20 mins. Then the data was analyzed to obtain the linear regression equation. The value of the correlation coefficient $\left(\mathrm{R}^{2}\right)$ represents linearity. ${ }^{17}$

\subsubsection{Accuracy}

Accuracy was measured by determining the percent recovery (\%). ${ }^{18}$ Three series of formaldehyde solution with 3 variations of concentration of $2.0 \mathrm{ppm} ; 2.5 \mathrm{ppm}$; and 3.0 ppm reacted with Schryver reagent for 20 mins. All three concentrations were observed at the maximum wavelength.

\subsubsection{Precision}

Three series of formaldehyde solution with 3 variations of concentration of $2.0 \mathrm{ppm}$; $2.5 \mathrm{ppm}$; and $3.0 \mathrm{ppm}$ reacted with Schryver reagent for 20 mins. All three concentrations were observed at the maximum wavelength. Precision was expressed as the value of the relative standard deviation or coefficient of variation. ${ }^{18}$

\subsubsection{Limit of Detection (LOD) and Limit of Quantification (LOQ) \\ From the standard curve that has been}


obtained, LOD and LOQ was calculated using the equation below: ${ }^{18}$

$$
L O D=\frac{3\left(\frac{S x}{y}\right)}{\text { slope }} \quad L O Q=\frac{10\left(\frac{5 x}{y}\right)}{\text { slope }}
$$

2.5. Optimization of Sample Preparation Methods

2.5.1.Preparation of meatballs simulation sample

The ingredients for making simulation meatballs were; $400 \mathrm{~g}$ minced meat, 2 finely sprinkled onion seeds, 2 finely sprinkled garlic seeds, 2 eggs, $1 / 2$ cup of sweet potato flour or corn flour, a little black and white pepper powder and a pinch of salt.

Minced meat was put in a container, mixed starch, eggs, ground pepper, salt and garlic that has been mashed. The ingredients were kneaded by hand until they were completely blended. Water was boiled in a pan until it boils. Meat dough taken by the hand and then formed round. The dough that has formed was put into boiling water. Continue until all the dough runs out. When the meatball has floated then the meatballs have been cooked and can be lifted.

\subsubsection{Preparation of simulation samples}

The simulation samples were prepared by soaking the prepared meatballs with formaldehyde at the concentration of $8 \mathrm{ppm}$, $12 \mathrm{ppm}$, and $16 \mathrm{ppm}$ for $24 \mathrm{hr}$. After that, the sample was extracted using 3 methods to see the best recovery value. In this study, the methods used were distillation, hot immersion, and cold immersion.

\subsubsection{Distillation}

The simulation samples were weighed to get $10 \mathrm{~g}$ of the sample then cut into small pieces and placed into a distillation tube, 50 $\mathrm{ml}$ of water and $5 \mathrm{ml}$ of $10 \%$ phosphoric acid were added and then distilled. Destilate was then accommodated in Erlenmeyer, covered by plastic wrap. ${ }^{19}$ The distillate product was pipetted $5 \mathrm{ml}$ and reacted with Schryver reagent, allowed to stand for $20 \mathrm{mins}$, then tested using a UV-Vis Spectrophotometer.

\subsubsection{Heat immersion}

The simulation samples were weighed to get $10 \mathrm{~g}$ of the sample, then cut into small pieces. It was put in the beaker, then $50 \mathrm{ml}$ of water was added. Then it was heated $5 \mathrm{hr}$ at $40^{\circ} \mathrm{C}$, shaken for 5 mins every $1 \mathrm{hr}$. Let it cool, filtered into a $100 \mathrm{ml}$ measuring flask. Water was added, then centrifuged. ${ }^{7}$ The filtrate was pipetted $5 \mathrm{ml}$ and reacted with Schryver reagent, allowed to stand for 20 mins, then tested using UV-Vis Spectrophotometer.

\subsubsection{Cold immersion}

The simulation samples were weighed to get $10 \mathrm{~g}$ of the sample, then cut into small pieces. It was put in the beaker, then $50 \mathrm{ml}$ of water was added. Then it was shaken for 5 mins every $1 \mathrm{hr}$. Leave at room temperature, filtered into a $100 \mathrm{ml}$ measuring flask. Water was added, then centrifuged..$^{10}$ The filtrate was pipetted $5 \mathrm{ml}$ and reacted with Schryver reagent, allowed to stand for 20 mins, then tested using UV-Vis Spectrophotometer.

\subsection{Formaldehyde Analysis in Sample Test} Samples of meatballs were taken from 5 meatball traders who have a stall settled in Jatinangor, Bandung. The sample was prepared by the optimum method that has been obtained.

\subsection{Qualitative Analysis of Formaldehyde on Meatballs}

Schryver method was used to identify formaldehyde in meatballs. The prepared filtrate was drip 3-5 drops into the test tube and then added 5 drops of Schryver reagent. The change of color to bright red shows positive results.

\subsection{Quantitative Analysis of Formaldehyde on Meatballs \\ The filtrate obtained from the positive} sample qualitatively was pipetted $5 \mathrm{ml}$ and placed in the Erlenmeyer. Schryver reagent was added, then it was homogenized, kept for 20 mins, and tested using UV-Vis Spectrophotometer.

\section{Results}

The maximum wavelength of 100 ppm of formaldehyde treated with Schryver 
reagent was at $519 \mathrm{~nm}$ (Figure 1).

Recovery for the preparation methods were $100.64 \%, 98.11 \%, 94.17 \%$, respectively for distillation, hot immersion, and cold immersion. The linear regression equation for the best method, distillation was $\mathrm{y}=0.0186 \mathrm{x}$ - 0,0093 with $\mathrm{R}^{2}=0,9994$ (Figure 2). The validation data was on Table 1.

Qualitatively, 2 samples showed positive reactions, ie, samples $\mathrm{B} 2$ and $\mathrm{B} 5$ and negative results on samples B1, B3 and B4. The quantitative test of meatball samples taken around Jatinangor showed that B2 sample contain formaldehyde as much as $17.02 \mathrm{ppm}$ and B5 sample containing formaldehyde as much as $8.77 \mathrm{ppm}$.

\section{Discussion}

The maximum wavelength of $100 \mathrm{ppm}$ of formaldehyde treated with Schryver reagent was at $519 \mathrm{~nm}$. This value was slightly different from the results obtained from previous research that was at $518 \mathrm{~nm}$. However, these results suggest that the formaldehyde solution remains on the appropriate spectrum because of small and not very significant differences. According to the Directorate General of Indonesia National Agency of Drug and Food Control, the maximum permissible wavelength tolerance for a range of $400 \mathrm{~nm}$ to $600 \mathrm{~nm}$ was approximately $3 \mathrm{~nm} .{ }^{20}$

The simulation sample preparation process was made using simulated samples that have been made, the first step was cutting the sample up to the size of $1 \mathrm{~cm} \times 1 \mathrm{~cm}$. It was intended that the added formaldehyde can seep into the meatball sample. Then the

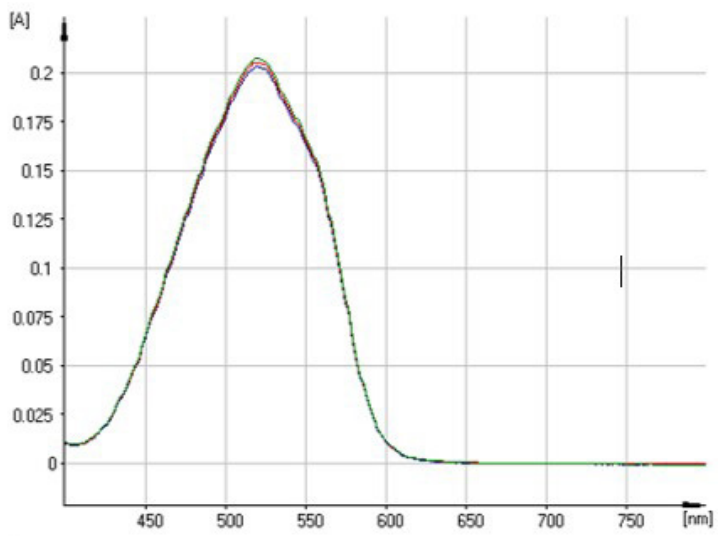

Figure 1. The maximum wavelength of formaldehyde sample was weighed as much as $10 \mathrm{~g}$, aiming for the number of samples used for testing. In previous research, many researchers used only about $5 \mathrm{~g}$ of the sample, but in this study, $10 \mathrm{~g}$ was used to ensure more accurate results.

After that, the sample was soaked using formaldehyde with 3 concentrations of $8 \mathrm{ppm}$, $12 \mathrm{ppm}$ and $16 \mathrm{ppm}$ for 24 hours, after that it was treated according to the preparation methods. In hot and cold immersion methods, samples were placed into Erlenmeyer and $50 \mathrm{ml}$ of water was added and immersion for $5 \mathrm{hr}$. In the method of heat immersion, the sample was heated at $40^{\circ} \mathrm{C}$ to separate formaldehyde with protein. Thereafter, the immersion results were filtered using filter paper to separate the immersion results with impurities such as residual meatballs and oils. Then centrifugation was done to obtain the results of the immersion that was affected by actual formaldehyde without additional ingredients such as protein, fat and others. In the distillation method, the sample was placed into a distillation flask, then $50 \mathrm{ml}$ of water and $5 \mathrm{ml}$ of phosphoric acid was added. Phosphoric acid acts as a catalyst to speed up the separation reaction between formaldehyde and protein. ${ }^{21}$ The sample was then distilled off with steam distillation at a temperature of $90^{\circ} \mathrm{C}-94^{\circ} \mathrm{C}$. The distillation product was collected in Erlenmeyer and covered with plastic wrap so that the formaldehyde did not evaporate.

From the calculated recovery value, the best preparation method was distillation method with an average percentage of recovery, $100.64 \%$ which was greater than heat immersion that was $98.61 \%$ and cold immersion that was $94.17 \%$. The precision of the method was indicated by the value of $\%$

Table 1. Validation data

\begin{tabular}{cc}
\hline Parameter & Result \\
\hline Accuracy & $100.03 \%$ \\
Presicion & $1.374 \%$ \\
LOD & $0.36 \mathrm{ppm}$ \\
LOQ & $0.46 \mathrm{ppm}$ \\
\hline
\end{tabular}




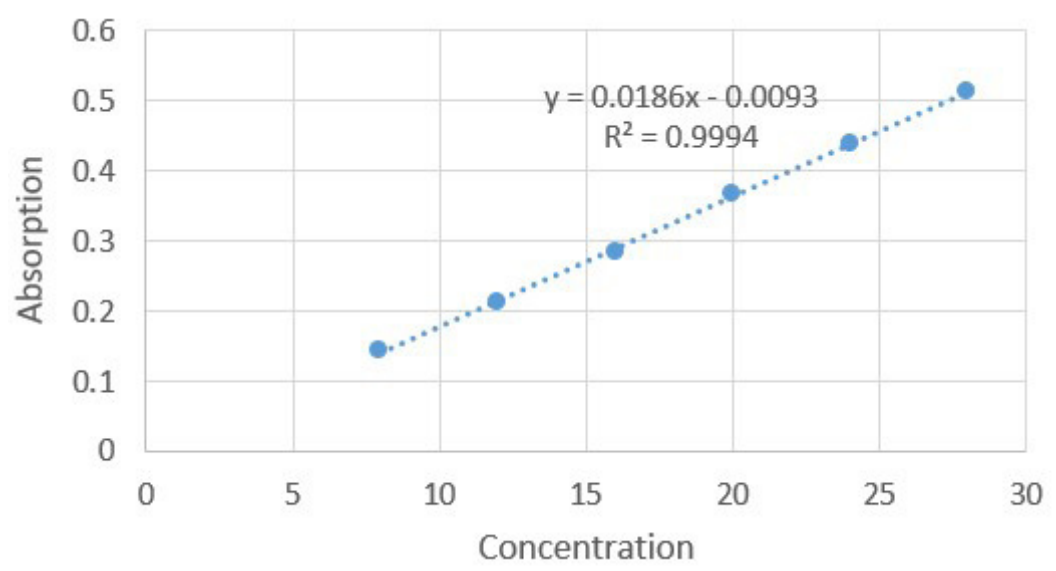

Figure 2. Calibration curve for formaldehyde standards

RSD, where the \% RSD value of the cold soaking method, heat immersion, and distillation were $1.568,0.513$ and $2.167 \%$, respectively.

Cold immersion was done at room temperature and shake for 5 mins every $1 \mathrm{hr}$ while soaked for $5 \mathrm{hr}$. This method was tried because the reaction of methylene is a reversible reaction. Formaldehyde was a material that easily dissolves in water because formaldehyde is polar and water is also polar. The difference of osmotic pressure between meatballs with the soaking solution which was water, causing the displacement of formaldehyde molecules from meatballs to water. $^{22}$

Hot and cold immersion was carried out for $5 \mathrm{hr}$, according to previous research which states that immersion can extract formalin to $6 \mathrm{hr}$ of immersion but may be influenced by the temperature factor and the type of protein tested. ${ }^{23}$ In hot soaking methods, methylene compounds were able to break down again into protein and formaldehyde, in the presence of factors such as the hot temperature of the water used. The perfection of the decomposition of methylene compounds could be achieved in $3 \mathrm{hr}$ by the soaking method so that the decomposition of the protein was achieved due to factors such as hot temperature and shaking. These factors play an important role in the decomposition of methylene as described. ${ }^{24}$ Heating aims to separate the bond between formalin and protein in meatballs because temperatures above $37^{\circ} \mathrm{C}$ will cause degradation of the protein. ${ }^{25}$
In the distillation method, although the sample was heated at boiling temperature $\left(90-94^{\circ} \mathrm{C}\right)$, the volatile formaldehyde will be collected back into the Erlenmeyer that has been attached to the distillation apparatus, causing the distillation method to have a better recovery when compared to the method of heat immersion which uses only $40^{\circ} \mathrm{C}$. The temperature for this method of heat immersion was chosen in accordance with research conducted by Herman, Maryati, and Yuanki in 2010 who conducted formaldehyde analysis of fish and shrimp samples. ${ }^{26}$ However, the results of the recovery test of the heat immersion method were not as high as the distillation method, this was because the inserted formaldehyde has evaporated into the air and was degraded. In addition, according to previous studies, if in an open system, the higher the temperature used the higher the formaldehyde content decomposes. ${ }^{22}$ Based on the results obtained, the distillation method was proved to have the best assay recovery and precision values between the three methods.

The test sample was collected and prepared using the most optimum method result from the optimization of the sample preparation method, which was the distillation method. Distillates were then tested qualitatively and quantitatively.

In testing on samples of meatballs taken around Jatinangor, selected meatballs are those that have bright and rather solid color features, have no odor, and if left outside the refrigerator was not damaged. Samples taken around Jatinangor were labeled with B1, B2, 
B3, B4, and B5, these samples were prepared by the distillation method, the distillate was then reacted with Schryver reagents and allowed to stand for 20 mins for discoloration.

Qualitatively, 2 samples showed positive reactions, ie, samples B2 and B5 and negative results on samples B1, B3 and B4. Physically, the samples B2 and B5 had the brightest color and had a smooth texture and solid. Positive results can be seen with the color change from clear to red.

Using the distillation method, a positive result of the qualitative test was then tested using UV-Vis spectrophotometry. The quantitative test of meatball samples taken around Jatinangor showed that B2 sample contain formaldehyde as much as $17.02 \mathrm{ppm}$ and B5 sample containing formaldehyde as much as $8.77 \mathrm{ppm}$. Both samples contained formadehyde with considerable concentration, which according to the Regulation of the Minister of Health Number 033 in 2012 About Food Additives, permits altogether the use of formaldehyde in foodstuffs. ${ }^{8}$

A considerable concentration of formadelhyde in the meatballs indicates that there were still many meatball traders who get hazardous chemicals easily and misused these chemicals in foodstuffs so there was a need for stricter supervision of the Food and Drug Administration to all meatballs pedigree as well as the sale of chemicals to the artisan meatballs and other food traders.

\section{Conclusion}

The best preparation method of formaldehyde analysis in meatballs was the distillation, with a recovery value of $100.65 \%$. Formaldehyde analysis on 5 samples of meatballs around Jatinangor qualitatively showed a positive reaction with the color change in 2 samples, B2 and B5. The result of the quantitative analysis showed that the formaldehyde concentration contained in the sample B2 was $14.72 \mathrm{ppm}$ and in the sample B5 was 8.7 ppm.

\section{References}

1. Checkoway H, Dell L, Boffeta $\mathrm{P}$, Gallagher A, Crawford L Lees P, et al.
Formaldehyde exposure and mortality Risks From Acute Myeloid Leukemia and Other Lymphohematopoietic Malignancies in the US National Cancer Institute Cohort Study of Workers in Formaldehyde Industries. Journal of Occupational and Environmental Medicine. 2015;57(7):785-794.

2. Swenberg JA, Moeller BC, Lu K, Rager JE, Fry R, Starr TB. Formaldehyde Carcinogenicity Research: 30 Years and Counting for Mode of Action, Epidemiology, and Cancer Risk Assessment. Toxicologic Pathology. 2013;41(2):181-189.

3. Zhang L, Tang X, Rothman N, Vermeulen R, Ji Z, Sehn, M, et al. Occupational Exposure to Formaldehyde, Hematotoxicity, and LeukemiaSpecific Chromosome Changes in Cultured Myeloid Progenitor Cells. Cancer Epidemiology, Biomarkers and Prevention. 2010;19(1):80-88

4. Jayalakshmi K, Ravikumar H, Jaya N, Raju R. A silent killer in the laboratory - Formaldehyde: Review of effects and management. International Journal of Oral and Maxillofacial Pathology. 2011;2(2):13-19

5. International Agency for Research on Cancer. Monographs on the evaluation of carcinogenic risks to humans, vol. 88, formaldehyde, 2-butoxyethanol and 1-tert-butoxy-2-propanol. Lyon, France: IARC; 2004.

6. NTP 12th Report on Carcinogens. Formaldehyde. National Toxicology Program. 2011. PMID: 21822324

7. Committee on Diet, Nutrition, and Cancer. Diet, Nutrition, and Cancer. National Academy Press. Washington DC: National Academy of Sciences; 1982.

8. Minister of Health regulation No 033. Food Additives. 2012. Retrieved on May 21, 2018 from http://jdih.pom. go.id/produk/peraturan $\% 20$ menteri/ Permenkes\%20ttg\%20BTP.pdf

. Saraswati, Tyas R. Research on the effect of formalin, diazepam, and 
alcoholic drinks on the body system. 2009. Retrieved on May 21, 2018 from Website: https://media.neliti.com/media/ publications/129945-ID-pengaruhformalin-diazepam-dan-minuman-b.pdf

10. Wicaksono. Analysis of formalin in fish and fresh shrimp with modified Schryver reagent (thesis). Depok, Indonesia: University of Indonesia; 2011.

11. Wulan. Identification of formalin in meatballs from meatball traders in Panukkang District, Makassar City (thesis). Makassar, Indonesia: Hasanudin University; 2015.

12. Safari M, Yamini Y, Tahmasebi E, Latifeh F. Extraction and preconcentration of formaldehyde in water by polypyrrolecoated magnetic nanoparticles and determination by high-performance liquid chromatography. Journal of Separation Science. 2015;38(19):3421-3427.

13. Tasooji M, Frazier CE. Simple milligramscale extraction of formaldehyde from wood. ACS Sustainable Chemistry and Engineering. 2016;4(9):5041-5045.

14. Zhu Y, Peng Z, Wang M, Wang R, Rui L. Optimization of extraction procedure for formaldehyde assay in smoked meat products. Journal of Food Composition and Analysis. 2012;28(1):1-7.

15. Hill AA, Lipert RJ, Frirz JS, Porter MD. A rapid, simple method for determining formaldehyde in drinking water using colorimetric-solid phase extraction. Talanta. 2009;77(4):1405-1408.

16. Fatimah N, Nurhasnawati H, Zaki R. Formalin Identification in Wet Noodles using Schryver Reagent. Jurnal Ilmiah Manuntung. 2018;4(1):74-78.

17. Ermer J and Miller J.H.M. Method validation in pharmaceutical analysis: a guide to best practice. United States: John Wiley \& Sons; 2005.

18. International Conference on Harmonization. Q2 Validation of analytical procedures : text and methodology international conference on harmonization of technical requirements for registration of pharmaceutical for human use. Canada: ICH Harmonized Tripartite Guideline; 2005.

19. Beitirevi.Optimization ofphenylhydrazine $\mathrm{HCl}$ in Schryver reagent for analysis of formalin in wet noodles in Cimahi City with visible spectrophotometry (thesis). Cimahi, Indonesia: General Achmad Yani University; 2017.

20. National Agency of Drug and Food Control of Republic of Indonesia, Indonesia Pharmacopoeia. 5th ed. Jakarta: Ministry of Health; 2014.

21. Reuss W, Disteldorf A. O, Gamer A. H. Formaldehyde" in Ullmann's encyclopedia of industrial chemistry. Weinheim: Wiley-VCH; 2005.

22. Farid, M, Akyunul, J, and Anik, M. (2015). The temperature and time influence of immersion in water solvent against formaldehyde salted level belanak fish (Mugil cephalus). Alchemy Journal of Chemistry. 2015;4(II):121-126.

23. Purawisastra dan Sahara. The adsorption of formaldehyde by some foodstuffs and its elimination by soaking them in hot water. Penelitian Gizi Makanan. 2011;34(1):63-74.

24. Thavarajah R, Mudimbaimannar V. K, Elizabeth J, Rao U.K, Ranganathan K. Chemical and physical basics of routine formaldehyde fixation. Journal of Oral and Maxillofacial Pathology. 2012;16(3):400405.

25. Elviani. (2013). Effect of temperature and duration of heating on protein levels contained in white swallow's nest (Collocalia Fuciphagus) (thesis). Bandung, Indonesia: Maranatha Christian University; 2013.

26. Herman, S, Maryati S, Yuanki, M. Analysis of Formalin in Fish and Shrimp from Muara Angke Market. Majalah Ilmu Kefarmasian. 2010;VII(3):1631. Retrieved from: http://ejournal. undip.ac.id/index.php/sm/article/ download/3279/2943 